\title{
Effect of prolactin on the production of progesterone by mouse ovaries in vitro
}

\author{
K. P. McNatty, P. Neal* and T. G. Baker* \\ M.R.C. Unit of Reproductive Biology, 39 Chalmers Street, and \\ *Hormone Laboratory, Department of Obstetrics and Gynaecology, University of Edinburgh, \\ Edinburgh, EH3 9ER, U.K.
}

Prolactin constitutes part of the luteotrophic complex necessary for the maintenance and secretory activity of the CL in the rat (Evans, Simpson, Lyons \& Turpeinen, 1941; Astwood, 1941), mouse (Kovacic, 1964), rabbit (Spies, Hilliard \& Sawyer, 1968), hamster (Greenwald \& Rothchild, 1968), ferret (Donovan, 1963), pig (du Mesnil du Buisson, 1973), and sheep (Denamur, Martinet \& Short, 1973). There is also evidence from in-vitro studies that low concentrations of prolactin are essential for the production of progesterone by preovulatory human granulosa cells (McNatty, Sawers \& McNeilly, 1975; McNatty, Bennie, Hunter \& McNeilly, 1976) while high concentrations are inhibitory (McNatty et al., 1976). In the present study the effect of various concentrations of prolactin on the production of progesterone by mouse ovaries in organ culture with or without luteal tissue was investigated, and the effects of rat, sheep or human prolactin preparations on ovarian steroidogenesis were compared.

Mice of the Schofield albino strain were given an i.p. injection of 5 i.u. PMSG (Gestyl: Organon Laboratories) at 25 or 28 days of age. Forty hours later the animals were either killed by cervical dislocation (animals without $\mathrm{CL}$ ) or given an ovulating injection of 2 i.u. HCG (Pregnyl: Organon Laboratories) and killed $24 \mathrm{hr}$ later (animals with CL). The ovaries were removed, cut into fragments and set up in the organ culture system of Neal, Baker, McNatty \& Scaramuzzi (1975). The culture was maintained (i) without added hormones; (ii) with prolactin (rat, NIAMD-RP1; ovine, NIH-PS8; human, Friesen preparation); (iii) with prolactin + ovine FSH (NIH-FSH-S9) + LH (NIH-LH$\mathrm{S} 18)$; (iv) ovine FSH + LH (1 $\mu \mathrm{g} / \mathrm{ml}$ of each). After $24 \mathrm{hr}$ in culture the medium was removed and stored at $-18^{\circ} \mathrm{C}$ until assayed for progesterone by the method of Neal et al. (1975). The ovarian fragments were fixed in Bouin's aqueous fluid and serial sections of the ovaries were examined for the presence or absence of $\mathrm{CL}$ and for the number of oocytes which resumed meiosis.

Neither rat nor ovine prolactin significantly influenced the number of oocytes undergoing preovulatory maturation in ovaries without luteal tissue (control $9 \cdot 5 \pm 2 \cdot 1$, treated $10 \cdot 0 \pm 1 \cdot 8$ ). There was, however, a significant inverse correlation between the concentration of prolactin in the culture medium and the production of progesterone by the ovaries without CL (Table 1). The inhibitory effect of prolactin on the production of progesterone was not related to the age of the animal or to the source of prolactin. There was a significant positive correlation between the concentration of prolactin in the culture medium and the production of progesterone by the ovaries which contained $C L$, regardless of the age of the animal and the source of prolactin. Ovaries from 28-day-old mice which were exposed to LH + FSH produced significantly more progesterone than did controls $(P<0.01$, Student's $t$ test $)$, but the linear correlation between increasing concentrations of prolactin and progesterone production persisted $(r=0.56, P<0.01$, by linear regression analysis).

These studies confirm and extend the earlier in-vitro studies of McNatty et al. (1975) for human granulosa cells, and suggest that prolactin may have a direct role in regulating ovarian steroidogenesis in the mouse. High concentrations of prolactin appear to enhance steroidogenesis by the CL but inhibit that by the developing follicles. This divergent action may be important in regulating follicular development during periods of stress, during pregnancy, or in lactational anoestrus when there are elevated concentrations of prolactin in plasma (see review by Horrobin, 1974).

Some of the expenses incurred in this study were defrayed from a grant to T.G.B. from the 
Table 1. Effect of prolactin on production/24 hr of progesterone by mouse ovaries in vitro

\begin{tabular}{|c|c|c|c|c|c|}
\hline \multicolumn{2}{|l|}{ Treatment } & \multicolumn{2}{|c|}{ 25-day-old ovaries } & \multicolumn{2}{|c|}{ 28-day-old ovaries } \\
\hline $\begin{array}{c}\text { Type of } \\
\text { hormone added }\end{array}$ & $\begin{array}{c}\text { Dose } \\
(\mathrm{ng} / \mathrm{ml})\end{array}$ & $\begin{array}{l}\text { With } \\
\text { CL }\end{array}$ & $\begin{array}{l}\text { Without } \\
\text { CL }\end{array}$ & $\begin{array}{l}\text { With } \\
\text { CL }\end{array}$ & $\begin{array}{l}\text { Without } \\
\text { CL }\end{array}$ \\
\hline Control & - & $54 \cdot 0 \pm 6 \cdot 3$ & $68 \cdot 7 \pm 16.5$ & $49 \cdot 2 \pm 17 \cdot 7$ & $56 \cdot 7 \pm 10 \cdot 9$ \\
\hline Rat prolactin & $\begin{array}{r}50 \\
100 \\
500 \\
1000\end{array}$ & $\begin{array}{l}45 \cdot 0 \pm 5.6 \\
73 \cdot 6 \pm 10.6 \\
87.0 \pm 15 \cdot 2 \\
85.6 \pm 10.0\end{array}$ & $\begin{array}{l}69 \cdot 3 \pm 21 \cdot 2 \\
52 \cdot 8 \pm 17.8 \\
37 \cdot 0 \pm 9.9 \\
23.0 \pm 6.8\end{array}$ & $\begin{array}{l}- \\
- \\
-\end{array}$ & $\begin{array}{r}22 \cdot 6 \pm 7 \cdot 6 \\
15 \cdot 9 \pm 3 \cdot 1 \\
7 \cdot 6 \pm 2 \cdot 7 \\
5 \cdot 7 \pm 1 \cdot 0\end{array}$ \\
\hline Ovine prolactin & $\begin{array}{r}50 \\
100 \\
500 \\
1000 \\
5000\end{array}$ & $\begin{array}{l}48 \cdot 4 \pm 4 \cdot 2 \\
65 \cdot 6 \pm 8 \cdot 3 \\
77 \cdot 7 \pm 9 \cdot 1 \\
87.9 \pm 10 \cdot 6 \\
\quad\end{array}$ & $\begin{array}{c}65 \cdot 3 \pm 11 \cdot 3 \\
53 \cdot 0 \pm 22 \cdot 3 \\
34 \cdot 2 \pm 11 \cdot 8 \\
34 \cdot 5 \pm 6 \cdot 5 \\
\quad\end{array}$ & $\begin{array}{r}74 \cdot 7 \pm 11 \cdot 0 \\
106 \cdot 4 \pm 22 \cdot 0 \\
108 \cdot 4 \pm 24 \cdot 0 \\
162 \cdot 5 \pm 37 \cdot 4\end{array}$ & $\begin{array}{c}27 \cdot 0 \pm 6 \cdot 5 \\
28 \cdot 9 \pm 7 \cdot 6 \\
16 \cdot 7 \pm 3 \cdot 0 \\
8 \cdot 2 \pm 4 \cdot 0 \\
-\end{array}$ \\
\hline Human prolactin & $\begin{array}{r}50 \\
250 \\
1000\end{array}$ & - & - & $\frac{-}{-}$ & $\begin{array}{l}33 \cdot 0 \pm 9 \cdot 5 \\
22 \cdot 6 \pm 8 \cdot 8 \\
13 \cdot 3 \pm 4 \cdot 7\end{array}$ \\
\hline $\mathbf{F S H}+\mathbf{L H}$ & - & - & - & $108 \cdot 3 \pm 15 \cdot 1$ & - \\
\hline FSH + LH + ovine prolactin & $\begin{array}{r}100 \\
500 \\
1000 \\
5000\end{array}$ & $\frac{-}{-}$ & $\begin{array}{l}- \\
- \\
-\end{array}$ & $\begin{array}{l}140 \cdot 3 \pm 31.6 \\
163.0 \pm 17 \cdot 1 \\
230 \cdot 0 \pm 58 \cdot 0 \\
350 \cdot 4 \pm 63.8\end{array}$ & $\begin{array}{l}- \\
- \\
-\end{array}$ \\
\hline
\end{tabular}

Linear regression analysis established the following significant correlations between prolactin concentration and progesterone production:

25-day-old ovaries: with CL; rat prolactin, $r=0.45, P<0.01$; ovine prolactin, $r=0.52, P<0.01$; without $C L$; rat prolactin, $r=0.41, P<0.01$; ovine prolactin, $r=0.36, P<0.05$.

28-day-old ovaries: with $C L$ and ovine prolactin, $r=0.48, P<0.01$; without $C L$, ovine prolactin, $r=0.58$, $P<0.01$, rat prolactin, $r=0.58, P<0.01$; human prolactin, $r=0.43, P<0.05$. With prolactin + LH + FSH the corresponding correlation was $r=0.56, P<0.01$.

Population Council, New York; K.P.McN. was the recipient of a New Zealand N.R.A.C. Fellowship. We thank Dr H. G. Friesen for the human pituitary prolactin preparation; the N.I.A.M.D. for the rat and sheep prolactin and the FSH and LH preparations; and Dr K. K. Dighe for the progesterone antiserum.

\section{References}

Astwood, E.B. (1941) Regulation of corpus luteum function by hypophysial luteotropin. Endocrinology 28, 309-320.

Denamur, R., Martinet, J. \& Short, R.V. (1973) Pituitary control of the ovine corpus luteum. $J$. Reprod. Fert. 32, 207-220.

Donovan, B.T. (1963) The effect of pituitary stalk section on luteal function in the ferret. $J$. Endocr. 27, 201-212.

DU Mesnil DU Buisson, F. (1973) Facteurs luteotropes chez la truie. In Le Corps Jaune, pp. 225-237. Eds R. Denamur \& A. Netlar. Masson et Cie, Paris.

Evans, H.M., Simpson, M.E., Lyons, W.R. \& TURPEINEN, K. (1941) Anterior pituitary hormones which favour the production of traumatic uterine placentoma. Endocrinology 28, 433-445.

GREenWALD, G.S. \& RoTHCHILD, I. (1968) Formation and maintenance of corpora lutea in laboratory aminals. J. Anim. Sci. 27, Suppl. 1, 139-162.

Horrobin, D.F. (1974) Prolactin 1974. Eden Press, Montreal.

Kovacic, N. (1964) Biological characteristics of pituitary and placental hormones. J. Reprod. Fert.8, 165-186. MCNatTy, K.P., Sawers, R.S. \& McNeilly, A.S. (1975) A possible role for prolactin in control of steroid secretion by the human Graafian follicle. Nature, Lond. $250,653$.

MCNatty, K.P., Bennie, J.G., Hunter, W.M. \& MCNeILLY, A.S. (1976) The effects of antibodies to human gonadotrophins on the viability and rate of progesterone secretion by human granulosa cells in tissue culture. In Physiological Effects of Immunity against Hormones, pp. 41-66. Eds R. G. Edwards \& M. H. Johnson. Cambridge University Press.

Neal, P., Baker, T.G., McNatTy, K.P. \& ScaramuzzI, R.J. (1975) Influence of prostaglandins and human chorionic gonadotrophin on progesterone concentration and oocyte maturation in mouse ovarian follicle maintained in organ culture. $J$. Endocr. 65, 19-25.

Spies, H.G., Hilliard, J. \& Sawyer, C.H. (1968) Pituitary and uterine factors controlling regression of corpora lutea in intact and hypophysectomized rabbits. Endocrinology 83, 291-299. 